\title{
ERratun
}

Volume 28, No. 4, page 95. It is regretted that through error Lord Robinson was referred to as Lord Robertson.

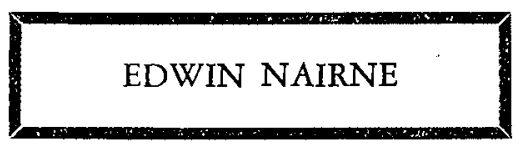

Edwin Nairne, a Forest Engineer, BC. Registered Forester and member of the Canadian Institute of Forestry, passed away in his home on January 11 , 1953.

He came from Scotland in 1905 to spend a number of years with Clark and Lyford before going to $\mathrm{H}$. Gardiner and Co. Through his years of activity, Edwin Nairne probably made as many topographical maps, road locations, and timber cruises as any other man in British Columbia. He thereby became one of the best known men in his field, and was highly respected for his integrity and ability backed by thirty-five years of experience.

He will be greatly missed by all who knew him in both forestry and the logging industry.

Submitted by H. GARDINER.

\section{W. B. SOUTHON}

In the death of W. Bruce Southon on August 10, 1952, Forest Industries lost an able operator and the Institute a staunch supporter.

Born at Fort William in 1903 and educated in the Fort William Public and High Schools, he entered employment with the Imperial Bank in 1923 but soon became interested in the opportunity offered in woods work and started his career in the woods in 1925. Working in different phases of the operations, clerical and scaling particularly, with C. W. Cox Limited and Hammermill Paper Company over a period of six years, he became associated with The Great Lakes Paper Company in 1931 and advanced rapidly from Scaler to Walking Boss, and to Logging Superintendent in 1937. In 1946 he became General Superintendent of Woodlands and shortly thereafter he was appointed Woods Manager, the appointment which he held at the time of his death.

In May 1940 he became an affiliate of the Canadian Society of Forest Engineers and was active in the North-Western Section from the date of its creation. He was author of "Loading Pulpwood On Vessels" published by the Woodlands Section of the Canadian Pulp and Paper Association in 1938. 